\title{
Analysis of the Problems in Language Teachers' Action Research
}

\author{
Ligang $\operatorname{Han}^{1}$ \\ ${ }^{1}$ English Department, North China Electric Power University, Baoding, Hebei, China \\ Correspondence: Ligang Han, English Department, North China Electric Power University, Baoding, Hebei, \\ China. E-mail: liganghan@163.com
}

Received: August 25, 2017

doi:10.5539/ies.v10n11p123
Accepted: September 30, $2017 \quad$ Online Published: October 28, 2017

URL: https://doi.org/10.5539/ies.v10n11p123

\begin{abstract}
In-service language teachers' professional development is a crucial factor that influences the teaching and learning effectiveness. Educational action research is considered by many researchers and scholars as an effective way or approach for language teachers' professional development. This article reports a case study of in-service English language teachers doing action research within a collaborative action research project. The focus of the case study is upon investigating the problems and difficulties that English language teachers encounter in doing action research and some solutions to the problems are provided. This research sheds light on the practice and application of educational action research.
\end{abstract}

Keywords: action research, language teacher development, problems

\section{Introduction}

It is believed that the modern action research in educational contexts can be traced back in the work of John Dewey (Burns, 2005). American social-psychologist, Kurt Lewin, is often credited with coining the term action research around 1934 (Mills, 2007). Action research provides a bridge that links theory and teaching practice.

Many researchers and scholars (e.g., Han, 2012; McNiff \& Whitehead, 2010; Mertler, 2009; Mills, 2007; Wallace, 1998; Wang, 2002; Wang \& Zhang, 2012) consider action research as an effective approach or way for language teachers' professional development. However, many in-service English language teachers have not recognized the effectiveness of fulfilling their professional development through action research.

In the present study, a collaborative action research project which acts as an exploration of the theory into practice, has been conducted between the university teacher researchers and in-service senior high school English language teachers in a metropolitan district in Beijing, China. The university teacher researchers act as guide, supporter, helper, and research assistants to the senior high school English language teachers.

During the one year and a half period, a variety of activities and sessions have been designed and organized to ensure the smooth movement of the project. The overall guideline for organizing the activities is based on the discovery, analysis of the problems that language teachers might encounter during the process. The sessions include lectures, seminars, workshops, and group discussions. Research data, gathered from questionnaires, interviews, reflection journals and so on are analyzed during the course.

Based on the recognition of the problems and difficulties, measures have been taken to guide, support, and help language teachers to continue and fulfill their action research journey. In the present paper, some main problems faced by the English language teachers are analyzed and possible solutions are also provided, which may shed light on the practice and application of educational action research in reality.

\section{Brief Review of Action Research}

The discussion of action research entails the argument of different definitions initiated and proposed by scholars and researchers. In this part, some representative definitions of action research are reviewed and explicated.

According to Mills (2007, p. 5), action research is "any systematic inquiry conducted by teacher researchers, principals, school counselors, or other stakeholders in the teaching/learning environment to gather information about how their particular schools operate, how they teach, and how well their students learn". Mills (2007) further asserts that this information is gathered with the goals of "gaining insight, developing reflective practice, effecting positive changes in the school environment (and on educational practices in general), and improving student outcomes and the lives of those involved". 
Creswell (2008, pp. 609-612) described action research as "a dynamic, flexible process that involves the following steps: Determining if action research is the best design to use; Identifying a problem to study; Locating resources to help address the problem; Identifying necessary information; Implementing the data collection; Analyzing the data; Developing a plan for action, and Implementing the plan and reflect".

Burns (1999) argues that action research is an approach which involves "a self-reflective, systematic and critical approach to enquiry by participants who are at the same time members of the research community".

Kemmis and Taggart (1982, p. 5) regard action research as "a form of self-reflective enquiry undertaken by participants in social (including educational) situations in order to improve the rationality and justice of: (a) their own social or educational practices; (b) their understanding of these practices; (c) the situations (and institutions) in which these practices are carried out". This definition is widely and commonly accepted by scholars and researchers.

Based on the different definitions discussed above, it is noted that the main characteristics of action research include "self-reflective, action-based, context specific, empirical, participatory, collaborative and aiming for change and improvement" (Wang, 2002).

As a matter of fact, there are many literatures on the definitions of action research and practices of promoting language teacher development through action research approach. However, the empirical research on the problems that language teachers encounter is scarce.

\section{The Action Research Project}

This part explains the research background of the action research project and the present case study, which includes the form of the action research project and the information about the case study.

\subsection{The Action Research Project Form}

The action research project follows a collaborative action research form (Wang \& Zhang, 2012). There are 17 teacher researchers, including six university teacher educators, eight $\mathrm{PhD}$ and three MA students from the Research Center for Foreign Language Education and Teacher Education in a key normal university in Beijing, China. The participants of the collaborative action research project consisted of 45 in-service English language teachers from 12 senior high schools in a district in Beijing. The 45 senior high school English language teachers were divided into subgroups according to the principle that teachers from the same school stayed as much as possible in the same group. Each group of the participants of the action research project consisted of two to nine members on average, and each group was allocated with one or two university teacher researchers to work with (Wang \& Zhang, 2012).

As a teacher researcher, I was responsible for one subgroup of the action research project that consisted of four English language teachers at the beginning of the project. They were all female English language teachers with several years of teaching experience respectively. Three of them were teaching Grade Two, and one was teaching Grade One in a senior high school in Beijing, China.

\subsection{The Case Study within the Collaborative Action Research Project}

Besides assisting the English language teachers to complete their action research project, a case study was carried out to find out the problems and difficulties that English language teachers would encounter at the different stages of the action research process. Most important of all, what can teacher researchers do to help and assist the in-service English language teachers to solve these problems?

Therefore, the research questions for the case study are as following.

1) What problems and difficulties will the English language teachers encounter while doing action research?

2) How to address and help English language teachers to solve these problems?

The case study ran for 18 months just as the collaborative action research project. To answer the two research questions of the case study, relevant research data were collected.

The research data were mainly qualitative, including interviews, observation notes, reflection journals of the participants and reflection journals/notes of the researcher. The qualitative data were transcribed, sorted, organized, and analyzed according to "content analysis" and "thematic analysis" (Patton, 2002).

Following Patton's (2002) "content analysis" and "thematic analysis" method, firstly, different forms of research data were carefully sorted and coded and then categorized based on the research questions. Secondly, the frequency of each code was counted to identify distinctive and prominent themes. Thirdly, cross-data analysis was conducted. As a result, the themes emerged from the data have no predetermined theoretical assumptions 
(Wang \& Zhang, 2014).

\section{Problems and Solutions in Language Teachers' Action Research}

In this part, the research findings of the case study are reported and discussed. Namely, what kind of problems did English language teachers' encounter at different stages of the action research process? What solutions and measures that could be taken to help English language teachers to solve and address these problems?

English language teachers encountered different types of problems while doing the action research. Research instruments such as in-depth interviews, reflection journals by the participants and teacher researchers were adopted to find out the problems that English language teachers were confronted with.

\subsection{Participants' Dropping out due to Various Reasons}

As mentioned above, there were four English language teachers in the small group at the beginning of the collaborative action research project. Because of family pressure, heavy workload and some unknown reasons, two English language teachers in this group dropped out from the project at the initial stage.

The two dropped out English language teachers were interviewed about the reasons why they quit the project. One teacher explained that her daughter was very young and she had to take care of her after finishing the teaching work at school. She simply could not have enough time and energy to spare for the action research project. The other teacher mentioned that just like many of her colleagues, she had much workload to do because her students would take the National Entrance Examination for Universities in a year's time. Although they were very enthusiastic about the action research project, they had to make such choice.

At the end of the collaborative action research project, in total, out of the 45 participants of the action research project, 11 English language teachers dropped out due to various reasons such as illness, family pressure and heavy workload.

\subsection{Participants' Misunderstandings and Confusion about Action Research at the Initial Stage}

Because the English language teachers have different academic and educational background, in the beginning, some teachers who took part in the action research project knew little about action research. They wondered what action research is and how different it is from the other basic and applied types of research.

To help to clarify the perplexities and clear the confusion, a lecture was delivered to explain action research process and the differences between action research and the other types of research.

In the lecture, the process of action research (see Figure 1) is clearly explicated so that the English language teachers could have a well-formed picture about the action research procedures that they would go through.

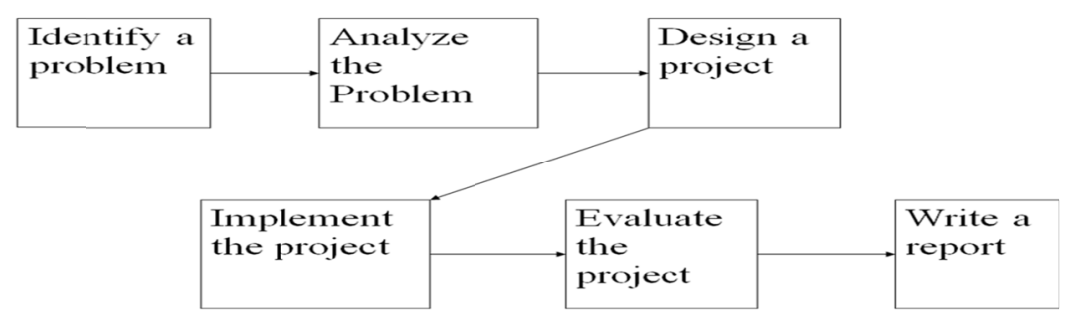

Figure 1. Action research process in linear form

As illustrated in Figure 1, the educational action research usually consists of the following major steps: Identifying an action research topic/problem; Analyzing the problem and narrowing down the research question(s); Designing/Planning for action research; Implementing and monitoring the action research plan/project; Evaluating and reflecting on the action research; Writing up action research report.

After explaining about the differences between the major characteristics of basic, applied and action research (see Table 1), English language teachers could understand what action research is and is not. 
Table 1. Major characteristics of basic, applied and action research (Burns, 2005, p. 61)

\begin{tabular}{|c|c|c|c|c|c|}
\hline $\begin{array}{l}\text { Research } \\
\text { type }\end{array}$ & $\begin{array}{l}\text { Philosophical } \\
\text { assumptions }\end{array}$ & Purpose & Main methods & Outcomes & Criteria for judgment \\
\hline Basic & $\begin{array}{l}\text { Universal truths } \\
\text { generalisable across } \\
\text { time and apace are } \\
\text { achieved through } \\
\text { scientific enquiry }\end{array}$ & $\begin{array}{l}\text { To establish } \\
\text { relationships among } \\
\text { phenomena, test } \\
\text { theory and generate } \\
\text { new knowledge }\end{array}$ & $\begin{array}{l}\text { Quantitative approaches, } \\
\text { hypothesis testing, control } \\
\text { of variables, rigorous } \\
\text { sampling }\end{array}$ & $\begin{array}{c}\text { Development of } \\
\text { theory }\end{array}$ & $\begin{array}{l}\text { Objectivity, verification } \\
\text { of theory, generalisablity, } \\
\text { rigor and reliability of } \\
\text { research methods, } \\
\text { published through } \\
\text { refereed, scholarly } \\
\text { journals }\end{array}$ \\
\hline Applied & $\begin{array}{c}\text { Societal phenomena } \\
\text { can be scientifically } \\
\text { studied and } \\
\text { understood }\end{array}$ & $\begin{array}{c}\text { To generate } \\
\text { understanding of } \\
\text { human behavior and } \\
\text { problems for the } \\
\text { purpose of } \\
\text { intervention }\end{array}$ & $\begin{array}{c}\text { Qualitative and } \\
\text { quantitative approaches, } \\
\text { data collection directed } \\
\text { towards ensuring } \\
\text { reliability and validity }\end{array}$ & $\begin{array}{c}\text { Development of } \\
\text { generalisable } \\
\text { theoretical } \\
\text { knowledge that can } \\
\text { be applied to the } \\
\text { social situation }\end{array}$ & $\begin{array}{l}\text { Objectivity, rigor and } \\
\text { scientific insights for } \\
\text { application to social } \\
\text { situations, published } \\
\text { through specialized, } \\
\text { refereed, applied journals }\end{array}$ \\
\hline $\begin{array}{l}\text { Action } \\
\text { research }\end{array}$ & $\begin{array}{l}\text { People within social } \\
\text { situations can solve } \\
\text { problems through } \\
\text { self-study and } \\
\text { intervention }\end{array}$ & $\begin{array}{c}\text { To develop solutions } \\
\text { to problems } \\
\text { identified within } \\
\text { ones' own social } \\
\text { environment }\end{array}$ & $\begin{array}{c}\text { Mainly qualitative, } \\
\text { interpretative, cases } \\
\text { studied reflectively } \\
\text { through cyclical } \\
\text { observational and } \\
\text { non-observational means }\end{array}$ & $\begin{array}{l}\text { Action to effect } \\
\text { change and } \\
\text { improvement, and } \\
\text { deeper } \\
\text { understanding in } \\
\text { one's own social } \\
\text { situation }\end{array}$ & $\begin{array}{l}\text { Subjectivity, feasibility, } \\
\text { trustworthiness, and } \\
\text { resonance or research } \\
\text { outcomes with those in } \\
\text { the same or similar social } \\
\text { situation }\end{array}$ \\
\hline
\end{tabular}

Besides the lecture, some books and journal articles on action research were recommended to the participants of the action research project.

From the interview with the two teachers in the case study group, it is learned that they had a clear idea and understanding about action research through attending the lecture organized by university teacher researchers and reading relevant books and journal articles on action research.

\subsection{Participants'Lack of Competence to Define Research Questions to Start the Action Research}

One aim of educational action research is to facilitate the professional development of reflective teachers. This can be exercised by asking the English language teachers to reflect on their daily teaching practice. Thus the first step in action research is to locate an educational problem and narrow it down to an operable extent.

English language teachers came up with all sorts of questions out of their perceptions of their classroom teaching. For instance, how to arouse students' interest in memorizing new English words and phrases? How to improve students' English listening comprehension ability? How to develop students' English reading and writing ability? However, these questions were too broad and general.

The teacher researchers asked the English language teachers to think of how to narrow down the general questions and define the research questions for their individual action research. And what kind of action plan to take to address the respective research questions?

With the help and assistance of the teacher researchers, the English language teachers could gradually narrow down their research questions and design an action research plan.

\subsection{Participants' Lack of Competence to Analyze the Research Data}

As Burns (2005, p. 62) points out that one of the major goals of action research is to "acquaint teachers with research skills and to enhance their knowledge of conducting research".

The fourth problem that English language teachers were confused about was the technical issues in the research strategies. It involves what research strategies and instruments could best suit the research questions, and how to analyze the quantitative and qualitative data collected during the action research process.

The research assistants facilitated the English language teachers by probing more into the research questions that the English language teachers were interested in their action research. Similarly, the two participants in the case study were given advice and suggestions on what research instruments that was conducive to address their research questions. 
The English language teachers were overwhelmed with the research data collected at the different stages of action research. For example, quantitative data gathered via questionnaires, and qualitative data such as interview transcripts, reflection journals and classroom observation notes.

I scaffolded the two participants after they collected research data for their action research on how to analyze the quantitative data and qualitative data. Moreover, I also recommended some softwares and books on research methods to the two participants.

\subsection{Solutions to the Problems in Language Teachers' Action Research}

As discussed above, various measures have been taken to clarify and tackle the misunderstandings, confusion, difficulties and problems that English language teachers had and encountered at different stages of the action research process.

The inner motives and needs analysis should be recognized at the initial stage of the project. Concerning the issue of lack of competence, collaboration was formed between university teacher researchers and in-service English language teachers.

A series of lectures, seminars, workshops were organized and delivered to help English language teachers at the different stages of the action research process. Teacher researchers also assisted English language teachers in their data collecting and analyzing stage.

In addition, English language teachers also need understanding and support from their family and institutions. Administration of the institutions should create conducive environment and context for the teachers' professional development through action research.

\section{Conclusion}

In brief, the major findings of the case study within the action research project are as following. Firstly, English language teachers have the need and desire to improve their teaching practice and realize their professional development through doing action research. However, some English language teachers have heavy workload, family pressure, and other reasons that force them to quit action research. As all of the senior high school teachers in China face the pressure to help their students to succeed in the National Entrance Examination for Universities, they have much teaching work to do, thus they simply cannot have extra time and energy to work on something "off their trade".

Administration of institution and schools should learn of the needs and desire of the in-service English language teachers for professional development, help them ease the burden, create supportive environment for their development.

Secondly, many English language teachers lack of competence to locate a teaching problem and define research questions to initiate. This situation can be changed and improved by attending some research seminars and workshops that facilitate the development of research competence.

Thirdly, English language teachers lack of research competence to analyze the research data. Similar to what has been discussed above, language teachers can read some books on research methods, and enhance their research competence through practice gradually.

As a matter of fact, the collaborative action research project between the university teacher researchers and in-service English language teachers has been very successful. Many participants in the collaborative action research project expressed their joy, happiness, and fulfillment in their reflection journals upon completing the "journey" (Wang \& Zhang, 2012).

During the action research project, the teacher researchers act more as scaffolding in guiding, counseling and supporting the English language teachers during the whole process. The measures and practice undertaken to solve the problems that English language teachers are confronted with in doing action research shall enrich the development of the action research theory.

\section{Acknowledgments}

This research was supported by "the Fundamental Research Funds for the Central Universities" (Grant NO. 13QN54).

\section{References}

Burns, A. (1999). Collaborative action research for English language teachers. Cambridge: Cambridge University Press. 
Burns, A. (2005). Action research: An evolving paradigm? Language Teaching, 38, 57-74. https://doi.org/10.1017/S0261444805002661

Burns, A. (2010). Doing action research in English language teaching: A guide for practitioners. New York: Routledge.

Creswell, W. J. (2008). Educational research: Planning, conducting and evaluating quantitative and qualititative research (3rd ed.). Upper Saddle River, N.J.: Pearson Education International.

Han, L. G. (2012). Action research: The route for English language teachers' professional development. In Q. Wang, \& H. Zhang (Eds.), The exploration of the practice of university-school collaborative action research (pp. 128-131). Shanghai: Shanghai Education Press.

Kemmis, S., \& McTaggart, R. (1982). The action research planner. Geelong, Victoria: Deakin University Press.

McNiff, J., \& Whitehead, J. (2009). Doing and writing action research. London: Sage.

McNiff, J., \& Whitehead, J. (2010). You and your action research project (3rd ed.). London: Routledge.

Mertler, C. A. (2009). Action research: Teachers as researchers in the classroom (2nd ed.). Los Angeles: Sage.

Mills, G. E. (2007). Action research: A guide for the teacher researcher (3rd ed.). Upper Saddle River, N.J.: Pearson Education, Inc.

Patton, M. Q. (2002). Qualitative research and evaluation methods (3rd ed.).Thousand Oaks, CA: Sage.

Wallace, M. J. (1998). Action research for language teachers. Cambridge: Cambridge University Press.

Wang, Q. (2002). Action research for English teachers: From theory to practice. Beijing: Foreign Language Teaching and Research Press.

Wang, Q., \& Zhang, H. (2014). Promoting teacher autonomy through university-school collaborative action research. Language Teaching Research, 18(2), 222-241. https://doi.org/10.1177/1362168813505942

Wang, Q., \& Zhang, H. (Eds.). (2012). The exploration of the practice of university-school collaborative action research. Shanghai: Shanghai Education Press.

\section{Copyrights}

Copyright for this article is retained by the author(s), with first publication rights granted to the journal.

This is an open-access article distributed under the terms and conditions of the Creative Commons Attribution license (http://creativecommons.org/licenses/by/4.0/). 